\title{
Prepartum nutrient intake alters palmitate metabolism by liver slices from peripartal dairy cows ${ }^{1}$
}

\author{
N. B. Litherland, ${ }^{2}$ H. M. Dann, ${ }^{3}$ and J. K. Drackley ${ }^{4}$ \\ Department of Animal Sciences, University of Illinois, Urbana 61801
}

\begin{abstract}
We determined the effects of day relative to parturition and prepartum plane of nutrition on hepatic partitioning of palmitate metabolism to $\mathrm{CO}_{2}$, acid-soluble products (ASP), and esterified products (EP). Multiparous Holsteins $(\mathrm{n}=74)$ were fed different amounts of nutrients during the dry period in a 3 (far-off period diet $) \times 2$ (close-up period diet) factorial arrangement. During the far-off period ( $\mathrm{d}-60$ to -25$)$ cows received a low-energy control diet fed ad libitum (100NRC) to meet National Research Council (NRC) requirements, a moderate-energy diet fed ad libitum to exceed NRC recommendations for net energy of lactation $\left(\mathrm{NE}_{\mathrm{L}}\right)$ by $>50 \%$ (150NRC), or the same diet fed at restricted intake to provide $80 \%$ of $\mathrm{NE}_{\mathrm{L}}$ requirements (80NRC). During the close-up period (d -24 until parturition), cows were fed a diet for ad libitum intake to meet NRC recommendations or in restricted amounts to provide $80 \%$ of calculated $\mathrm{NE}_{\mathrm{L}}$ requirements. After parturition, all cows had ad libitum access to a lactation diet. Liver slices from biopsies on $\mathrm{d}-30,-14,1,14$, and 28 relative to parturition were used to determine conversion of $\left[1-{ }^{14} \mathrm{C}\right]$ palmitate to $\mathrm{CO}_{2}$, ASP, and EP. Across diets, oxidation of palmitate to $\mathrm{CO}_{2}$ was decreased postpartum, whereas oxidation to ASP was increased at d 1 postpartum compared with other times. Conversion of palmitate to EP increased markedly postpartum, with the greatest rates at $\mathrm{d} 1$ postpartum. Conversion of palmitate to $\mathrm{CO}_{2}$ and ASP on d 1 postpartum was lower and the proportion of palmitate metabolism as EP was greater for cows fed 150NRC than for those fed 100NRC or 80 NRC. Hepatic triacylglycerol concentration at d 1
\end{abstract}

\footnotetext{
Received March 2, 2010.

Accepted December 21, 2010.

${ }^{1}$ Supported by federal and state funds appropriated to the Illinois Agricultural Experiment Station and award no. 2001-35206-10946 from the National Research Initiative Competitive Grants Program, Cooperative State Research, Education, and Extension Service, United States Department of Agriculture.

${ }^{2}$ Current address: University of Minnesota, Department of Animal Science, 155B Haecker Hall, 1364 Eckles Avenue, St. Paul, MN 55108-

${ }^{3}$ Current address: William H. Miner Agricultural Research Institute, Chazy, NY 12921.

${ }^{4}$ Corresponding author: drackley@uiuc.edu
} 6118.

postpartum was greatest for cows fed 150NRC. Palmitate metabolism did not differ between close-up diets. Hepatic triacylglycerol was negatively correlated with tissue metabolism of palmitate to $\mathrm{CO}_{2}$ and ASP but positively correlated with metabolism to EP. Hepatic triacylglycerol was highly correlated with NEFA concentrations on the day of calving and $\mathrm{d} 1$ postpartum but not with NEFA prepartum. In contrast, plasma BHBA postpartum was not correlated with hepatic palmitate metabolism by liver slices but was highly correlated with NEFA concentration prepartum. Excessive energy intake during the far-off dry period decreased hepatic palmitate oxidation and shifted palmitate metabolism toward greater esterification, consistent with greater hepatic triacylglycerol accumulation postpartum.

Key words: hepatic fatty acid metabolism, dry period, transition period

\section{INTRODUCTION}

Cows allowed ad libitum access to moderate quality diets during the dry period consume significant excesses of energy relative to their requirements (Dann et al., 2005; Douglas et al., 2006). Around parturition, such cows may have depressed appetite and greater mobilization of NEFA from adipose tissue triacylglycerol (TAG). Excessive body fat mobilization leads to increased uptake of NEFA by the liver. The liver accumulates TAG when the rate of hepatic NEFA esterification exceeds the rate of TAG removal through hydrolysis and secretion in very low density lipoproteins. In turn, fatty liver has been linked to an increased incidence of health disorders and poor milk production (Bobe et al., 2004). Additionally, costs of feeding large amounts of a higher energy diet during the dry period may not be recovered because a higher plane of nutrition during the dry period does not necessarily lead to higher milk yield postpartum (Douglas et al., 2006).

Nutritional state clearly can alter metabolic activities in liver tissue (Drackley et al., 1991a). Concentrations of total lipid and TAG in liver were lower at $d$ 1 and 21 after calving in cows fed a high-forage diet supplemented with fat compared with cows fed control or high grain diets during the dry period (Grum et 
al., 1996). Lower hepatic concentrations of total lipid and TAG were accompanied by decreased capacity for esterification of palmitate in liver slices incubated with nonlimiting concentrations of palmitate and increased peroxisomal $\beta$-oxidation in liver homogenates (Grum et al., 1996). Compared with limit-feeding diets to requirements, overfeeding during the dry period increased NEFA release from adipose tissue (Rukkwamsuk et al., 1998) and decreased enzymes of hepatic fatty acid oxidation postpartum, which contributed to postpartum accumulation of TAG in liver (Murondoti et al., 2004).

The effects of prepartum diets varying in energy density on the metabolic and enzymatic capacity of liver can be evaluated by measuring palmitate metabolism in liver slices obtained by biopsy from cows fed those diets. Application of liver slice technology offers the opportunity to challenge liver tissue with a concentration of NEFA in the upper physiological range and determine the effects of in vivo treatment on in vitro tissue metabolism of NEFA. A greater degree of palmitate esterification indicates that dietary treatment enhanced the liver's capacity to accumulate TAG; however, greater rates of palmitate oxidation should be associated with greater capacity to oxidize palmitate and thereby minimize the amount of TAG accumulation.

Our hypothesis was that cows fed a low energy diet formulated to meet NRC (2001) recommendations in the far-off period, followed by feeding a diet with increased nutrient density for 3 wk prepartum, would result in increased oxidation of palmitate and minimize accumulation of esterified products (i.e., TAG) in liver slices relative to cows that were allowed to overconsume energy during the entire dry period. The objectives of this experiment were to determine the effects of day relative to parturition and of far-off and close-up diets, varying in energy density and amount fed, on capacity for palmitate oxidation and esterification by liver slices in vitro. We also examined relationships between hepatic metabolism of palmitate and liver composition as well as metabolites in blood. Data for intake, production, liver composition, and blood chemistry from this study have been reported previously (Dann et al., 2006).

\section{MATERIALS AND METHODS}

\section{Cows and Treatments}

All procedures were conducted under protocols approved by the University of Illinois Institutional Animal Care and Use Committee. Data reported here were collected from cows in a larger experiment, from which experimental design, diets, and production data have been reported previously (Dann et al., 2006). Briefly,
74 cows were fed 1 of 3 far-off dry period diets from dry-off to -25 d relative to expected parturition. The control diet (100NRC) was formulated to meet but not greatly exceed National Research Council (NRC, 2001) recommendations for all nutrients during the faroff dry period when consumed at predicted ad libitum DMI. The higher nutrient density diet exceeded NRC (2001) recommendations for all nutrients during the far-off dry period and was fed for either ad libitum intake to allow at least $150 \%$ of NRC recommendations for $\mathrm{NE}_{\mathrm{L}}(\mathbf{1 5 0 N R C )}$ or in restricted amounts (80NRC) to allow only $80 \%$ of calculated $\mathrm{NE}_{\mathrm{L}}$ requirement of the cow based on BW at dry-off (NRC, 2001). The higher nutrient density diet was similar in composition to a typical close-up diet, but did not contain anionic salts.

From $-24 \mathrm{~d}$ relative to expected parturition until parturition, cows from each far-off treatment were randomly assigned to 1 of 2 close-up period treatments until parturition. The close-up diet met or exceeded NRC (2001) nutrient recommendations. The close-up diet was fed either for ad libitum intake to allow at least $150 \%$ of calculated $\mathrm{NE}_{\mathrm{L}}$ requirement or at restricted intake to provide $80 \%$ of calculated $\mathrm{NE}_{\mathrm{L}}$ requirement based on BW at dry-off (NRC, 2001). The close-up diet was similar to the far-off higher nutrient density diet except for the addition of anionic salts. Thus, treatments were in a $3 \times 2$ factorial arrangement of 3 far-off period treatments $(100 \mathrm{NRC}, \mathrm{n}=25 ; 150 \mathrm{NRC}, \mathrm{n}=25$; 80NRC, $\mathrm{n}=24)$ and 2 close-up period treatments (ad libitum, $\mathrm{n}=38$; restricted, $\mathrm{n}=36$ ). After parturition, all cows were fed a lactation diet. All diets were mixed once daily and fed as TMR. Approximately half of each diet was fed at $1100 \mathrm{~h}$ and the remainder was fed at $1700 \mathrm{~h}$. Alfalfa hay ( 2 kg DM daily) was top-dressed on the lactation diet until 14 DIM.

Cows were housed in tie stalls throughout the experiment and were allowed to exercise daily in an outside lot for $3 \mathrm{~h}$ (0700 to $1000 \mathrm{~h}$ ). Two weeks before expected parturition, cows were moved to box stalls until parturition. After parturition, cows were returned to tie stalls. Cows were milked twice daily (0300 and $1500 \mathrm{~h}$ ).

\section{Biopsies and In Vitro Metabolism Procedures}

In vitro metabolism of palmitate was measured in liver slices prepared from biopsies of liver obtained on target dates of $\mathrm{d}-30,-14,+1,+14$, and +28 relative to parturition. The actual days of biopsy (mean \pm SD) were $-27.9 \pm 5.3,-12.5 \pm 4.9,1.2 \pm 0.4,13.8 \pm 1.5$, and $27.4 \pm 1.7$. Liver was sampled via puncture biopsy (Hughes, 1962; Veenhuizen et al., 1991) from cows under local anesthesia at approximately $0700 \mathrm{~h}$. Biopsies $(\sim 1 \mathrm{~g})$ were placed in ice-cold phosphate-buffered (9 $\mathrm{m} M)$ saline $(0.9 \% \mathrm{NaCl})$ at $\mathrm{pH} 7.4$ and transported to 
the laboratory where liver slices were prepared using a Krumdieck tissue slicer (Alabama Research and Development, Munford, AL) equipped with a 5-mm-diameter tissue holder. An amount of liver tissue sufficient to perform all procedures was obtained from $67,59,56$, 60 , and 61 cows on target days $-30,-14,+1,+14$, and +28 , respectively.

Conversion of palmitate to $\mathrm{CO}_{2}, \mathrm{ASP}$, and intracellular EP by liver slices was measured using procedures based on those used by Drackley et al. (1991b) as modified (Grum et al., 1996). Slices (approximately $20 \mathrm{mg}$ ) were blotted and weighed into $25-\mathrm{mL}$ incubation flasks for a total of $\sim 40 \mathrm{mg}$ of tissue per flask. Slices were incubated in $3 \mathrm{~mL}$ of modified Krebs-Ringer bicarbonate (KRB) medium in which Na-HEPES $(25 \mathrm{mM})$ replaced an equimolar portion of $\mathrm{NaCl}$ (Cremin et al., 1994). The KRB medium contained Na-palmitate (2 $\mathrm{m} M$; MP Biomedicals, Irvine, CA) with $\left[1-{ }^{14} \mathrm{C}\right]$ palmitic acid $(0.3 \mu \mathrm{Ci}$; MP Biomedicals) complexed to fatty acid-free BSA (MP Biomedicals) in a 4:1 molar ratio. The medium also contained L-carnitine $\mathrm{HCl}$ (1 m $M$; Sigma, St. Louis, MO). Substrate concentrations were chosen based on preliminary experiments that determined that substrate was not limiting for maximal rates of metabolism (data not shown). After tissue loading was complete, flasks containing liver were gassed with $\mathrm{O}_{2}: \mathrm{CO}_{2}$ (95:5), sealed with a rubber septum, and incubated in a shaking water bath $(45$ cycles $/ \mathrm{min})$ at $37^{\circ} \mathrm{C}$ for $2 \mathrm{~h}$. All incubations were performed in triplicate.

For determination of $\mathrm{CO}_{2}$ and ASP, incubations were stopped by injecting $0.5 \mathrm{~mL}$ of $40 \% \mathrm{HClO}_{4}$ into the incubation medium, and $0.1 \mathrm{~mL}$ of $30 \% \mathrm{NaOH}$ was applied directly to folded filter paper (Whatman \#1, 42.5-mm diameter) in a glass well that was suspended in the flask using nylon monofilament. Blank flasks were processed identically except these flasks did not receive tissue and were stopped immediately. After incubations were stopped, flasks containing liver tissue and flasks incubated as blanks were shaken on ice for $1 \mathrm{~h}$ to collect $\mathrm{CO}_{2}$ in the hanging well. Incubation medium and hanging wells were processed as described previously by Drackley et al. (1991a,b) and transferred to scintillation vials. After processing, $10 \mathrm{~mL}$ of liquid scintillation cocktail (Scintisafe Econo 2, Fisher Scientific, Fair Lawn, NJ) was added to each vial. Radioactivity in $\mathrm{CO}_{2}$ and ASP ( $\sim 80 \%$ ketone bodies and acetate; Jesse et al., 1986b) was determined by liquid scintillation spectroscopy (Beckman LS 6000 IC, Beckman Instruments Inc., Fullerton, CA).

For measurement of palmitate conversion to EP, incubations were conducted in separate flasks that contained the same KRB medium as described for $\mathrm{CO}_{2}$ and ASP measurements. Flasks containing live tissue were incubated similarly except EP flasks did not contain a hanging well. Blank flasks contained liver tissue but the incubation medium was aspirated immediately. Following aspiration of incubation medium, $1 \mathrm{~mL}$ of $3 \%$ BSA in KRB buffer $\left(37^{\circ} \mathrm{C}\right)$ was added, the flask was vortexed, and the BSA was aspirated; this process was repeated with $3 \mathrm{~mL}$ of $0.9 \%$ saline followed by $1 \mathrm{~mL}$ of saline. Extraction of EP was conducted according to procedures described by Drackley et al. (1991a) and Grum et al. (1996), except that tubes were centrifuged at $1,000 \times g$, phase separation was conducted in disposable tubes rather than the original glass extraction tube, and scintillation vials containing solvent were dried overnight. When dry, $10 \mathrm{~mL}$ of scintillation cocktail (Scintisafe Econo 2, Fisher Scientific) was added to each vial and radioactivity was determined by liquid scintillation spectroscopy (model LS6000IC, Beckman Coulter, Inc.).

Average rates of triplicate flasks were corrected for tissue weight and background radioactivity by subtracting values obtained from blank flasks. Conversion to end products was calculated using the known amount of radioactivity present in each flask relative to the amount of radioactivity measured in end products following the 2-h incubation period. Data are expressed as nanomoles of palmitate converted to product (i.e., $\mathrm{CO}_{2}$, ASP, or EP) per hour per gram of liver (wet weight). Total palmitate metabolism was the sum of rates of conversion to $\mathrm{CO}_{2}, \mathrm{ASP}$, and EP.

\section{Statistical Analyses}

Statistical computations were performed using SAS (release 8.2, SAS Institute Inc., Cary, NC). All data were checked for normality and outliers before statistical analysis. Three separate analyses were performed. First, to compare rates of palmitate metabolism by day during the peripartal period irrespective of dietary treatments, data were subjected to ANOVA using the MIXED procedure of SAS (Littell et al., 1996). The model contained the effect of day relative to parturition (i.e., the target day for the biopsy), a dummy variable for dietary treatment (1 to 6 ; all combinations of faroff and close-up diets), and the interaction of day and the dummy treatment variable. Day was designated a repeated factor with cow nested within treatment as the subject. The ARH(1) covariance structure was used because of the heterogeneous variances among days. Least squares means for days were separated by using the PDIFF procedure of SAS.

Second, effects of diet on palmitate metabolism preand postpartum were determined. Data from the far-off period ( $-30 \mathrm{~d}$ relative to parturition), close-up period 
( $-14 \mathrm{~d}$ relative to parturition), and postpartum period $(+1,+14$, and +28 relative to parturition $)$ were analyzed separately. Because diets differed during the faroff dry period and close-up dry period, and postpartum data represented residual effects of dry period diets, we chose not to include all prepartum and postpartum data in a single repeated-measures analysis; this approach was also used for the full data set (Dann et al., 2006). Data for the far-off period were analyzed as a random design with a model that contained the effects of far-off treatment (100NRC, 150NRC, and 80NRC). Least squares means for far-off treatment effects were separated by use of the PDIFF statement when $P<$ 0.05 .

Data for the close-up period and postpartum period were analyzed as a randomized design with a $3 \times 2$ factorial arrangement of treatments (far-off treatments $\times$ close-up treatments). The model for close-up period data contained the effects of far-off treatment (100NRC, 150NRC, or 80NRC), close-up treatment (ad libitum or restricted), and the interaction of far-off and close-up treatments. Least squares means for far-off and close-up treatment effects were separated by use of the PDIFF statement when $P<0.05$.

Postpartum data (d 1, 14, and 28 relative to parturition) were analyzed together as a randomized design with repeated measures. The model contained the effects of far-off diet, close-up diet, the interaction of far-off and close-up diets, day postpartum, and the interactions of day with dietary treatments. The subject for the repeated effect of day was cow nested within far-off and close-up treatment, and the ARH(1) option was used to model covariance structure of the repeated measures. Where interactions with day were significant, the slice option in SAS was used to separate treatment by time effects.

Because on the basis of previous data we expected peripartal and dietary differences to be greatest at $\mathrm{d}$ 1 postpartum, the final statistical analysis determined effects of prepartum diets on data from d 1 postpartum separately. The model used for all variables (palmitate metabolism, liver composition, plasma metabolites, and insulin) included effects of far-off diet, close-up diet, and the interaction of far-off and close-up diets. Least squares means for far-off and close-up treatment effects were separated by use of the PDIFF statement when $P<0.05$.

Relationships between data for in vitro palmitate metabolism and liver composition and blood component concentrations (Dann et al., 2006) were analyzed by calculating Spearman correlations in SAS. Correlations were calculated both for the complete peripartal data set (all biopsy dates) and for d 1 postpartum separately.

\section{RESULTS}

\section{Changes in Palmitate Metabolism During the Peripartal Period}

On the basis of previous data for peripartal palmitate metabolism (Grum et al., 1996) and hepatic TAG concentrations (Vazquez-Añon et al., 1994; Grum et al., 1996; Van den Top et al., 1996), we expected that day relative to parturition would have marked effects on hepatic palmitate metabolism. Therefore, we analyzed the effect of day relative to parturition, irrespective of diet (Figure 1). Rates of conversion of palmitate to $\mathrm{CO}_{2}$ were low, ranging from $3.1 \%$ of total metabolism on $\mathrm{d}$ -30 to $2.2 \%$ of total metabolism on d 1 postpartum. Palmitate conversion to $\mathrm{CO}_{2}$ was greater prepartum than postpartum $(P<0.01)$. The rate of palmitate conversion to ASP tended to be affected by day relative to parturition $(P<0.10$ for overall effect), with means for d 1 being greater $(P<0.05)$ than those for $\mathrm{d}-30$, -14 , or 14 . Conversion to ASP ranged from $43.6 \%$ of total metabolism on $\mathrm{d}-30$ to a low of $38.5 \%$ of total on $\mathrm{d} 14$. The rate of palmitate conversion to EP was affected by day relative to parturition $(P<0.001)$, with rates being greater postpartum than prepartum. Means were greatest on d 1, and mean rates on d 14 were greater than those on $\mathrm{d} 28$. Conversion of palmitate to EP was the largest portion of total metabolism, ranging from $53.3 \%$ of total on $\mathrm{d}-30$ to a high of $59.2 \%$ on $\mathrm{d} 14$ postpartum. Total palmitate metabolism was affected by day relative to parturition $(P<0.001)$; means were greatest at d 1 and means for d 14 and 28 were not different from each other but greater than prepartum values. The concentration of TAG in liver tissue (\% of wet weight) was $0.27,0.57,1.91,3.65$, and 2.01 for $\mathrm{d}$ $-30,-14,1,14$, and 28 , respectively; all values differed from one another $(P<0.001)$ except that $\mathrm{d} 1$ and $\mathrm{d} 28$ did not differ from each other $(P=0.78)$.

\section{Effects of Prepartum Diet: Complete Peripartal Data Set}

Means for effects of far-off diets on in vitro metabolism of palmitate on $\mathrm{d}-30$ are presented in Table 1 . Complete oxidation of palmitate to $\mathrm{CO}_{2}$ by liver slices was greater $(P<0.05)$ for 100NRC than for 80NRC cows, with $150 \mathrm{NRC}$ cows intermediate. Incomplete oxidation of palmitate to ketone bodies as measured by ASP formation did not differ among far-off treatments. The rates of conversion of palmitate to EP and total palmitate metabolism were greater $(P<0.05)$ for $100 \mathrm{NRC}$ than for 80NRC cows, whereas $150 \mathrm{NRC}$ cows were intermediate (Table 1). When rates were expressed as percentages of total metabolism no difference was 
observed in partitioning of palmitate flux among far-off diets (Table 1).

Effects of far-off and close-up diets on palmitate metabolism during the close-up period $(\mathrm{d}-14)$ are shown in Table 2. Liver slices from $150 \mathrm{NRC}$ cows tended $(P=$ $0.08)$ to have greater rates of palmitate conversion to $\mathrm{CO}_{2}$ than did slices from 100NRC cows. The interaction of far-off and close-up treatments was significant because the combination of 150NRC plus ad libitum close-up resulted in greater conversion of palmitate to $\mathrm{CO}_{2}$ than all other dietary combinations. Conversion of palmitate to ASP and EP, as well as total palmitate metabolism, did not differ among far-off or close-up treatments.

Partitioning of total palmitate metabolism among $\mathrm{CO}_{2}$, ASP, and EP on $\mathrm{d}-14$ also is shown in Table 2. A trend for an interaction $(P=0.06)$ of far-off and closeup diets existed for both $\mathrm{CO}_{2}$ and ASP because the combination of $150 \mathrm{NRC}$ and ad libitum close-up diet resulted in greater percentages of palmitate converted to $\mathrm{CO}_{2}$ and ASP, but 150NRC plus restricted close-up decreased percentages to $\mathrm{CO}_{2}$ and ASP. Moreover, a significant interaction $(P=0.04)$ of far-off and close-up diets existed for partitioning of palmitate to EP on d -14 ; the combination of $150 \mathrm{NRC}$ and restricted intake of the close-up diet resulted in the greatest EP as a percentage of total palmitate metabolism

Data for palmitate metabolism by liver slices during the postpartum period are presented in Table 3. Faroff treatment tended $(P=0.08)$ to affect oxidation of palmitate to $\mathrm{CO}_{2}$ primarily because conversion to $\mathrm{CO}_{2}$ was greater $(P<0.05)$ on d 1 postpartum for 100NRC and $80 \mathrm{NRC}$ than for 150NRC (Table 1). Palmitate

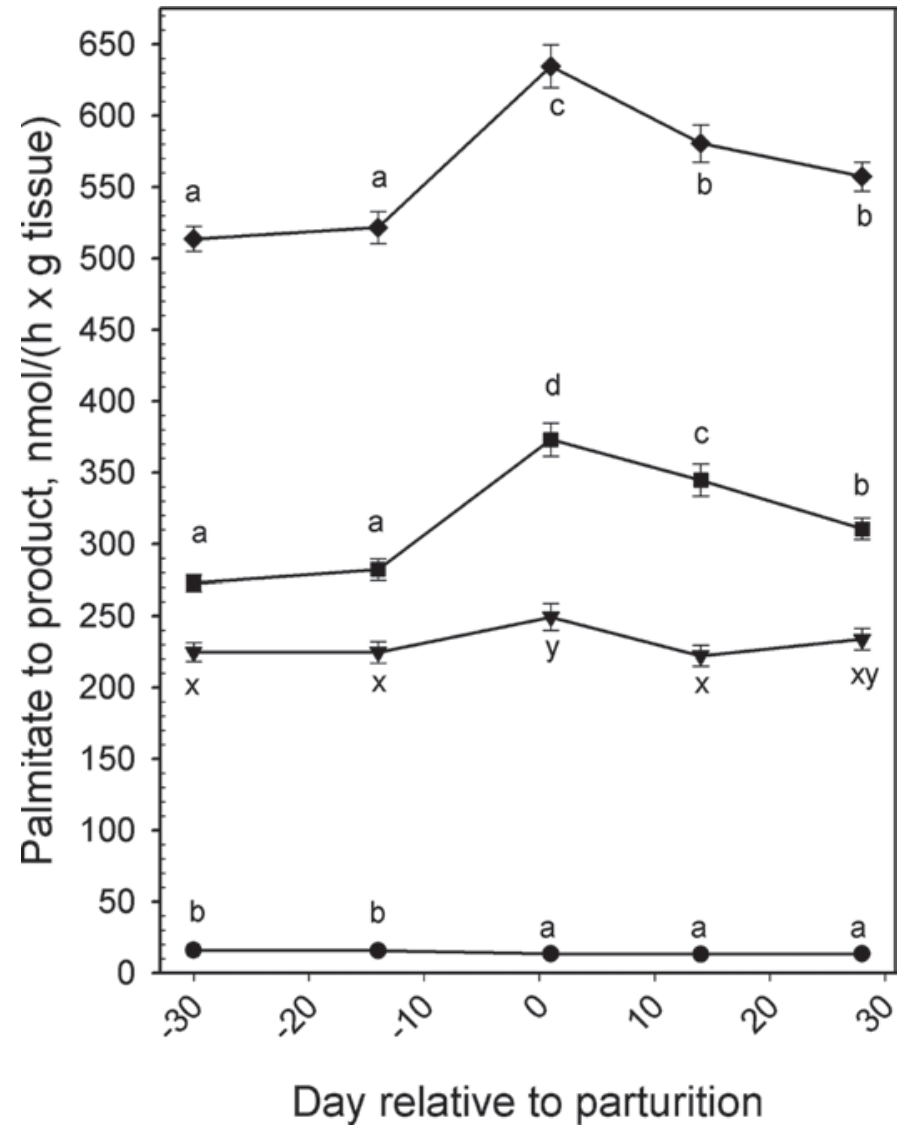

Figure 1. Rates of conversion of palmitate to total metabolic products $(\bullet)$, esterified products (EP; $\mathbf{\square})$, acid-soluble products (ASP; $\mathbf{\nabla})$, and $\mathrm{CO}_{2}(\bullet)$ by bovine liver slices in vitro, irrespective of prepartum diet. The effect of day relative to parturition was significant for rates of total metabolism $(P<0.001)$, EP $(P<0.001)$, and $\mathrm{CO}_{2}(P=0.002)$ and tended to be significant for ASP $(P=0.091)$. Means with different letters are significantly different $\left({ }^{\mathrm{a}-\mathrm{d}} P<0.05 ;{ }^{\mathrm{x}, \mathrm{y}} P<0.10\right)$.

Table 1. Least squares means and standard errors for main effects of far-off (FO) period dietary treatments on palmitate metabolism by liver slices from cows at $30 \mathrm{~d}$ before parturition

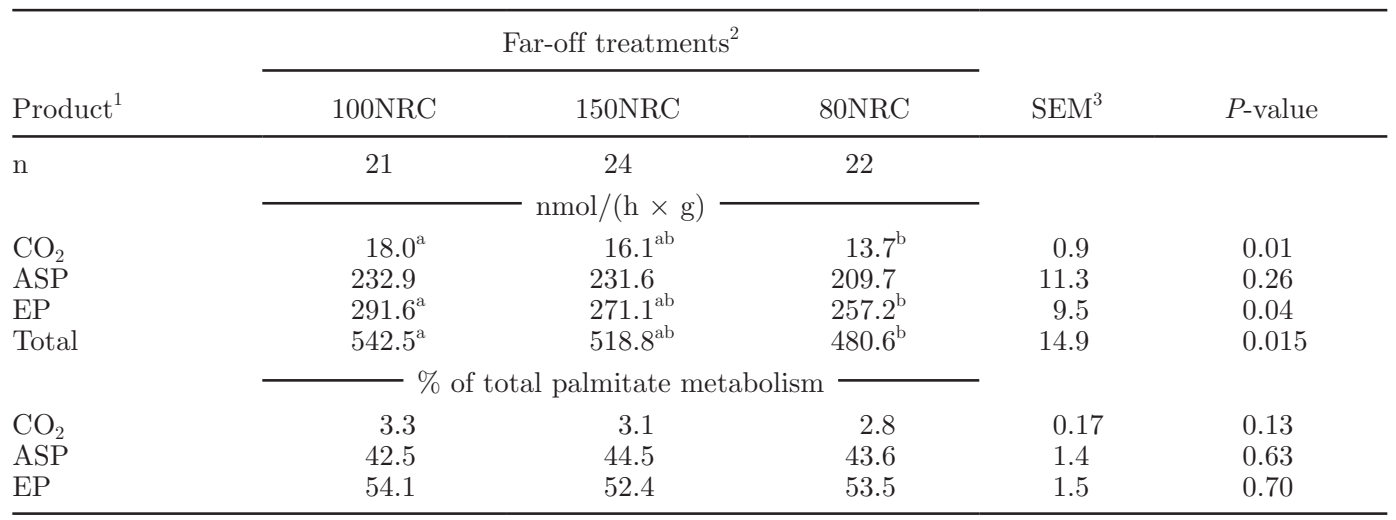

${ }^{a, b}$ Means in the same row with different superscripts differ $(P<0.05)$.

${ }^{1} \mathrm{ASP}=$ acid-soluble products; $\mathrm{EP}=$ esterified products; total $=\mathrm{CO}_{2}+\mathrm{ASP}+\mathrm{EP}$.

${ }^{2}$ Diets fed to meet $100 \%$ (100NRC), $150 \%$ (150NRC), or 80\% (80NRC) of NRC (2001) requirements for $\mathrm{NE}_{\mathrm{L}}$ during the far-off dry period.

${ }^{3}$ Largest SEM shown. 
Table 2. Least squares means and standard errors for interactions of far-off (FO) and close-up (CU) period dietary treatments on palmitate metabolism by liver slices from cows $14 \mathrm{~d}$ before parturition

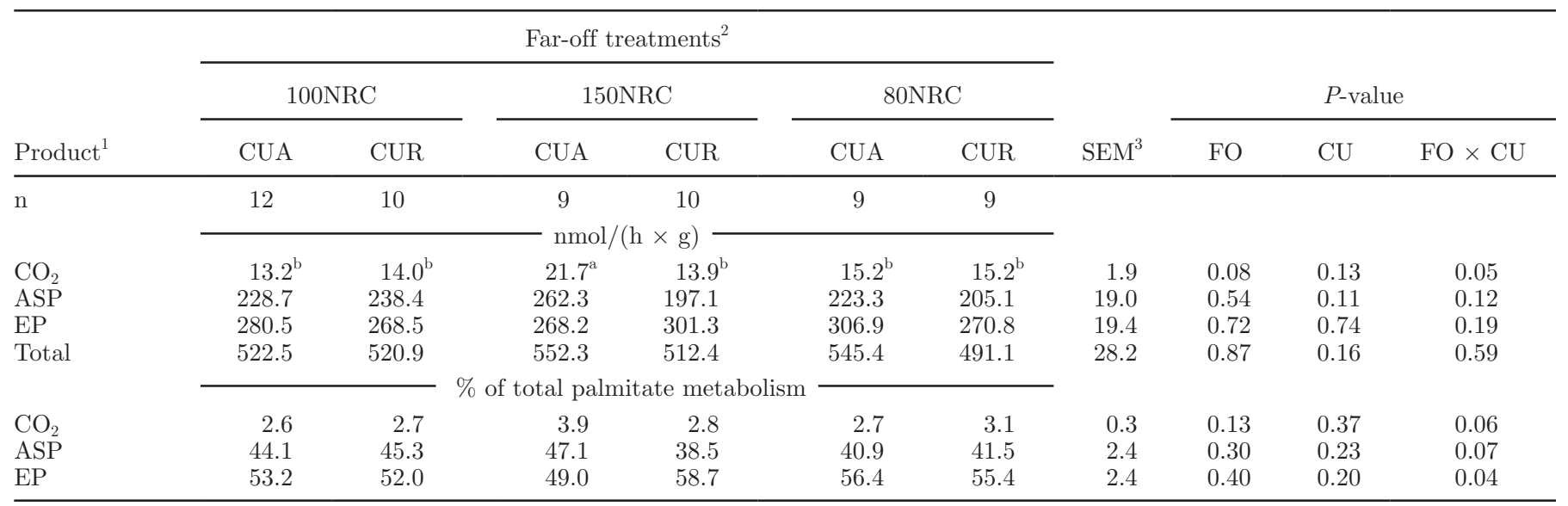

${ }^{\mathrm{a}, \mathrm{b}}$ Means in the same row with different superscripts differ $(P<0.05)$.

${ }^{1} \mathrm{ASP}=$ acid-soluble products; $\mathrm{EP}=$ esterified products; total $=\mathrm{CO}_{2}+\mathrm{ASP}+\mathrm{EP}$.

${ }^{2}$ Diets fed to meet $100 \%$ (100NRC), $150 \%$ (150NRC), or 80\% (80NRC) of NRC (2001) requirements for NE $\mathrm{L}_{\mathrm{L}}$ during the far-off dry period; closeup diets fed either ad libitum (CUA) or in restricted amounts (CUR).

${ }^{3}$ Largest SEM shown.

conversion to ASP was affected by a far-off treatment by day interaction. The slice option revealed that conversion to ASP was greater $(P<0.05)$ for $100 \mathrm{NRC}$ and $80 \mathrm{NRC}$ than for $150 \mathrm{NRC}$ on $\mathrm{d} 1$, but rates were not different among treatments on d 14 postpartum. On d 28, palmitate conversion to ASP by liver slices was greater $(P<0.05)$ for 100NRC than for either $150 \mathrm{NRC}$ or $80 \mathrm{NRC}$. Rates of palmitate esterification and rates of total palmitate metabolism decreased from d 1 to d 28 but were not affected by dietary treatments. Partitioning of total palmitate metabolism among $\mathrm{CO}_{2}$, ASP, and EP postpartum (Table 3) was not affected by prepartum diets or interactions of prepartum diet and day of biopsy.

Correlations among the variables measured on all biopsy days are presented in Table 4 . Concentrations of total lipid and TAG in liver were negatively correlated with palmitate conversion to $\mathrm{CO}_{2}$ but negative correlations with conversion to ASP were much weaker. In contrast, palmitate conversion to EP was positively correlated with both liver total lipid $(\mathrm{r}=0.547)$ and liver TAG $(r=0.530)$. Correlations of palmitate metabolism with liver glycogen were negative. Plasma NEFA and BHBA concentrations were negatively correlated with palmitate conversion to $\mathrm{CO}_{2}$, were not correlated with conversion to ASP, and were positively related to conversion to EP. Plasma insulin was not correlated with measures of palmitate metabolism, but was negatively related to liver total lipid and liver TAG as well as plasma NEFA and BHBA. Insulin was positively related to plasma glucose and liver glycogen.

\section{Effects of Prepartum Diet: Day 1 Data}

Means for liver metabolism, liver composition, and plasma BHBA, glucose, and insulin on d 1 as well as NEFA for $\mathrm{d}-2$ to $\mathrm{d} 1$ are shown in Table 5 . Oxidation of palmitate to ASP and $\mathrm{CO}_{2}$ by liver slices on $\mathrm{d} 1$ was affected by far-off diet, being lower for cows fed $150 \mathrm{NRC}$ than for those fed either $100 \mathrm{NRC}$ or $80 \mathrm{NRC}$. Neither close-up diet nor the interaction of far-off and close-up diets significantly affected palmitate metabolic rates. However, when rates were expressed as percentages of total metabolism, far-off diet affected conversion of palmitate to $\mathrm{EP}(P=0.03)$ and tended to affect conversion to ASP $(P=0.06)$. The proportion of total palmitate metabolism as EP was greater for cows fed 150NRC (62.5\%) than for those fed either 100NRC $(57.3 \%)$ or $80 \mathrm{NRC}(55.3 \%)$. Both liver total lipid and liver TAG concentrations were greater for cows fed $150 \mathrm{NRC}$ than for those fed $100 \mathrm{NRC}$ or $80 \mathrm{NRC}$ in the far-off dry period, but neither component was altered by close-up diet or the interaction. Plasma BHBA and glucose on d 1 were not affected by dry period treatments, but insulin tended $(P=0.06)$ to be greater for cows fed ad libitum during the close-up period than for those fed restricted amounts of the close-up diet.

Because increased NEFA are strongly related to development of fatty liver, we examined concentrations by treatment daily from $\mathrm{d}-2$ to $\mathrm{d} 1$ relative to parturition (Table 5 ). On $d-2$, NEFA were increased by restricted feeding of the close-up diet, without interaction with far-off diet. On d -1, NEFA were again increased only 
by the restricted close-up diet; the interaction of faroff and close-up diet did not achieve significance $(P=$ 0.15 ). On the day of calving (d 0 ), however, both faroff diet and close-up diet affected NEFA. Means were greater for cows previously fed 150NRC in the far-off dry period than for either $100 \mathrm{NRC}$ or $80 \mathrm{NRC}$. Restricted feeding of the close-up diet resulted in greater NEFA than ad libitum feeding, although this was primarily due to cows previously fed the 100NRC and 150NRC far-off diets (interaction of far-off and close-up diet, $P$ $=0.12$ ). At $\mathrm{d} 1$ postpartum, neither close-up nor far-off diet affected plasma NEFA.
Correlations among peripartal variables are shown in Table 6. Negative correlations between palmitate oxidation and either liver total lipid or liver TAG were larger for $d 1$ than for the entire data set. Plasma NEFA at d 1 postpartum was strongly related to palmitate conversion to EP, but was not correlated with measures of palmitate oxidation. In contrast, NEFA on d $-2,-1$, or 0 were not correlated with palmitate metabolism. Likewise, plasma NEFA on d 1 were highly correlated with liver total lipid and liver TAG concentrations and negatively correlated with liver glycogen; however, NEFA on the other days was not related to liver com-

Table 3. Least squares means and standard errors for interactions of far-off (FO) and close-up (CU) period dietary treatments on palmitate metabolism by liver slices postpartum

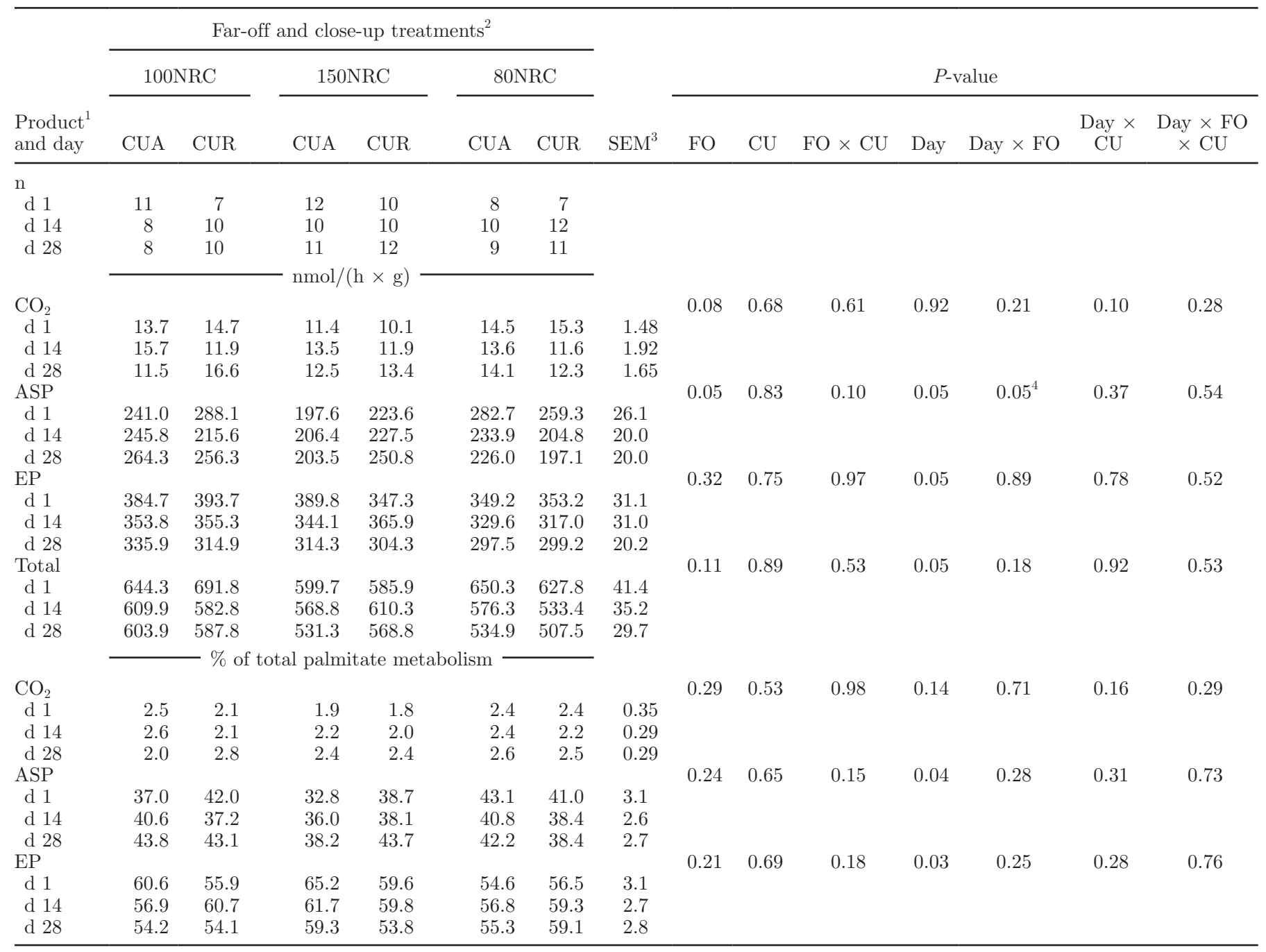

${ }^{1} \mathrm{ASP}=$ acid-soluble products; $\mathrm{EP}=$ esterified products; total $=\mathrm{CO}_{2}+\mathrm{ASP}+\mathrm{EP}$.

${ }^{2}$ Diets fed to meet $100 \%$ (100NRC), $150 \%$ (150NRC), or $80 \%$ (80NRC) of NRC (2001) requirements for NE $\mathrm{L}_{\mathrm{L}}$ during the far-off dry period; closeup diets fed either ad libitum (CUA) or in restricted amounts (CUR).

${ }^{3}$ Largest SEM shown.

${ }^{4}$ The slice option in SAS revealed that conversion to ASP was greater $(P<0.05)$ for $100 \mathrm{NRC}$ and $80 \mathrm{NRC}$ than for $150 \mathrm{NRC}$ on $\mathrm{d} 1$, but rates were not different among treatments on d 14 postpartum. On d 28, palmitate conversion to ASP was greater $(P<0.05)$ for $100 \mathrm{NRC}$ than for either 150NRC or 80NRC. 
Table 4. Spearman correlations among hepatic and plasma variables, across all sampling times ${ }^{1}$

\begin{tabular}{|c|c|c|c|c|c|c|c|c|c|c|}
\hline Variable $^{2}$ & $\mathrm{CO}_{2}$ & $\mathrm{EP}$ & $\begin{array}{c}\text { Total } \\
\text { metabolism }\end{array}$ & $\begin{array}{l}\text { Liver } \\
\text { total lipid }\end{array}$ & $\begin{array}{l}\text { Liver } \\
\text { TAG }\end{array}$ & $\begin{array}{c}\text { Liver } \\
\text { glycogen }\end{array}$ & $\begin{array}{l}\text { Plasma } \\
\text { NEFA }\end{array}$ & $\begin{array}{l}\text { Plasma } \\
\text { BHBA }\end{array}$ & $\begin{array}{l}\text { Plasma } \\
\text { glucose }\end{array}$ & $\begin{array}{l}\text { Plasma } \\
\text { insulin }\end{array}$ \\
\hline \multirow[t]{2}{*}{ ASP } & 0.401 & -0.009 & 0.612 & -0.132 & -0.122 & 0.007 & -0.037 & 0.067 & 0.159 & 0.067 \\
\hline & $<0.001$ & 0.88 & $<0.001$ & 0.022 & 0.035 & 0.90 & 0.53 & 0.25 & 0.006 & 0.25 \\
\hline $\mathrm{CO}_{2}$ & & $<0.001$ & 0.100 & $<0.001$ & $<0.001$ & $<0.001$ & $<0.001$ & 0.011 & 0.21 & 0.080 \\
\hline \multirow[t]{2}{*}{$\mathrm{EP}$} & & - & 0.730 & 0.547 & 0.530 & -0.437 & 0.494 & 0.299 & -0.087 & -0.107 \\
\hline & & & $<0.001$ & $<0.001$ & $<0.001$ & $<0.001$ & $<0.001$ & $<0.001$ & 0.14 & 0.066 \\
\hline Liver total lipid & & & & & $<0.001$ & $<0.001$ & $<0.001$ & $<0.001$ & 0.272 & $<0.001$ \\
\hline \multirow[t]{2}{*}{ Liver TAG } & & & & & - & -0.540 & 0.630 & 0.402 & -0.086 & -0.220 \\
\hline & & & & & & $<0.001$ & $<0.001$ & $<0.001$ & 0.13 & $<0.001$ \\
\hline \multirow[t]{2}{*}{ Liver glycogen } & & & & & & - & -0.580 & -0.386 & -0.001 & 0.288 \\
\hline & & & & & & & $<0.001$ & $<0.001$ & 0.99 & $<0.001$ \\
\hline Plasma NEFA & & & & & & & - & 0.468 & 0.012 & -0.330 \\
\hline
\end{tabular}

${ }^{1}$ Correlation coefficient (r) is top number, with corresponding $P$-value beneath.

${ }^{2} \mathrm{ASP}=$ acid-soluble products; $\mathrm{EP}=$ esterified products; $\mathrm{TAG}=$ triacylglycerol.

position. Plasma BHBA concentrations at d 1 were not correlated with in vitro palmitate oxidation, but were strongly correlated with NEFA concentrations. Correlations between d 1 BHBA and NEFA were larger for $\mathrm{d}-2,-1$, and 0 than for $\mathrm{d} 1$. Insulin at $\mathrm{d} 1$ was not correlated with liver metabolism and was only weakly associated with liver composition. Insulin was negatively correlated with d 1 plasma BHBA and NEFA on all days. Plasma glucose at $\mathrm{d} 1$ was negatively related to plasma NEFA and BHBA, although the correlations were small. Glucose was not correlated with any measure of in vitro palmitate metabolism.

\section{DISCUSSION}

We determined the effects of day relative to parturition and prepartum diet on in vitro metabolism of palmitate (as a representative NEFA) by liver slices. The partitioning of palmitate metabolism among conversion to $\mathrm{CO}_{2}$, ASP, and $\mathrm{EP}$ was generally similar to previous results using the same techniques (Drackley et al., 1991b). Rates of conversion of palmitate to $\mathrm{CO}_{2}$ were low, as expected (Jesse et al., 1986a,b; Drackley et al., 1991a,b), but decreased postpartum compared with rates measured in the prepartum biopsies. In contrast, palmitate conversion to ASP was not greatly affected across the transition, although rates were increased on d 1 relative to other times. The small decrease in rate of conversion of palmitate to $\mathrm{CO}_{2}$ and small increase in oxidation to ASP at $1 \mathrm{~d}$ postpartum indicate that palmitate oxidation likely would be shifted toward increased ketone body formation and less complete oxidation in the citric acid cycle. The most pronounced change in palmitate metabolism postpartum was in conversion to EP, which increased sharply on d 1 postpartum and remained higher than prepartum values on $\mathrm{d} 14$ and d 28 . Increased conversion to EP was the main factor driving overall increases in rates of total palmitate metabolism postpartum. The greater esterification rates at $\mathrm{d} 1$ and d 14 compared with rates of oxidation to $\mathrm{CO}_{2}$ and ASP help explain why bovine liver is prone to accumulation of TAG during the early postpartum period.

Diet during the far-off dry period in general had more pronounced effects on peripartal palmitate metabolism by liver slices in this study than did the close-up dietary treatments. In a similar manner, far-off dietary treatment had greater effect on other measures of metabolism and production than did close-up treatment (Dann et al., 2006). At d 1 postpartum, palmitate metabolism in liver slices from cows allowed to over-consume energy during the far-off dry period was shifted to a greater proportion of esterification and away from oxidation compared with cows in which energy intake was controlled during the far-off dry period. These changes are consistent with a greater likelihood to accumulate TAG in the liver during periods of NEFA mobilization, as demonstrated by the greater hepatic TAG and total lipid accumulation on d 1 postpartum for overfed cows in our study. Capacity of liver slices to oxidize palmitate was modestly correlated negatively with liver total lipid and liver TAG, whereas capacity for esterification of palmitate was highly correlated with concentrations 
Table 5. Least squares means for measurements in liver on $\mathrm{d} 1$ postpartum and in plasma around parturition for cows fed different combinations of far-off (FO) and close-up (CU) diets prepartum ${ }^{1}$

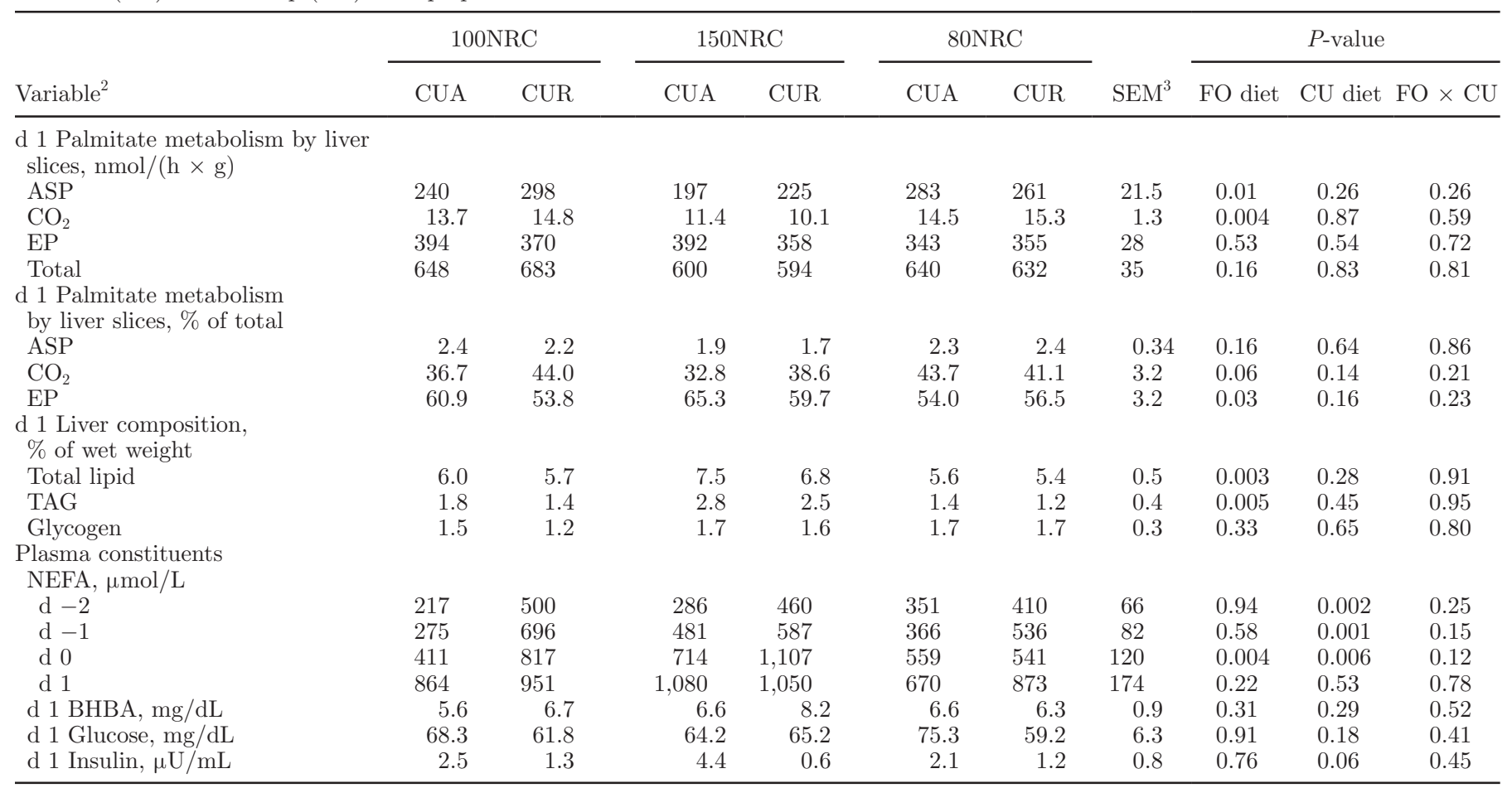

${ }^{1}$ Diets fed to meet $100 \%$ (100NRC), $150 \%$ (150NRC), or $80 \%$ (80NRC) of NRC (2001) requirements for NE $\mathrm{L}_{\mathrm{L}}$ during the far-off dry period; closeup diets fed either ad libitum (CUA) or in restricted amounts (CUR).

${ }^{2} \mathrm{ASP}=$ acid-soluble products; $\mathrm{EP}=$ esterified products; TAG = triacylglycerol.

${ }^{3}$ Largest SEM shown.

of total lipid and TAG in liver. These data indicate that either increasing oxidative capacity of liver or decreasing esterification would moderate the rate of TAG accumulation postpartum.

Maintaining optimal liver function by preventing excessive TAG accumulation may be central to the ability of cows to make a smooth transition into lactation (Bobe et al., 2004; Drackley and Andersen, 2006; Loor et al., 2007). Mobilization of adipose tissue TAG during periods of negative energy balance is an adaptive strategy to meet tissue energy demands and maintain homeostasis. Periparturient dairy cows may be challenged by hepatic TAG accumulation when the rate of NEFA mobilization exceeds the rate of hepatic NEFA oxidation and TAG export. Total oxidation capacity in liver homogenates was correlated negatively with concentrations of total lipid and TAG in liver, yield of solids-corrected milk, and plasma NEFA and was correlated positively with liver glycogen, DMI, energy balance, and plasma glucose for cows in early lactation (Grum et al., 2002). Additionally, the ratio of peroxisomal $\beta$-oxidation to total $\beta$-oxidation was correlated positively with liver total lipid, liver TAG, and plasma NEFA and negatively with DMI and energy balance
(Grum et al., 2002). A limited ability to increase hepatic NEFA oxidation following parturition in overfed cows may contribute to postpartum accumulation of liver TAG (Drackley and Andersen, 2006). Evidence for negative effects of dry period overfeeding on hepatic enzymes of NEFA oxidation has been reported by others (Murondoti et al., 2004).

Factors regulating the partitioning of NEFA between oxidation and esterification in the liver of periparturient dairy cattle have been difficult to elucidate. The primary site of regulation in nonruminants appears to be at the mitochondrial membrane and governs whether NEFA enter the mitochondria for oxidation or are diverted to glyceride formation via microsomal esterification (Zammit, 1999). Entry of NEFA into mitochondria for $\beta$-oxidation to $\mathrm{CO}_{2}$ or ketone bodies is controlled by the enzyme carnitine palmitoyltransferase-1 (CPT-1). Activity of CPT-1 in ruminants is inhibited by malonylCoenzyme A (CoA; Brindle et al., 1985; Dann and Drackley, 2005), the first committed intermediate of fatty acid synthesis. Subsequent to inhibition of CPT-1, malonyl-CoA inhibits mitochondrial palmitate oxidation (Jesse et al., 1986a; Dann and Drackley, 2005). Mitochondrial CPT-1 activity at d -30 was greater for 
Table 6. Spearman correlations among d 1 measurements in liver (in vitro palmitate metabolism by liver slices, liver composition) and metabolites in blood around parturition ${ }^{1,2}$

\begin{tabular}{|c|c|c|c|c|c|c|c|c|c|c|c|c|c|}
\hline Variable & $\mathrm{CO}_{2}$ & EP & $\begin{array}{c}\text { Total } \\
\text { metabolism }\end{array}$ & $\begin{array}{c}\text { Liver } \\
\text { total lipid }\end{array}$ & $\begin{array}{l}\text { Liver } \\
\text { TAG }\end{array}$ & $\begin{array}{c}\text { Liver } \\
\text { glycogen }\end{array}$ & $\begin{array}{c}\text { Plasma } \\
\text { NEFA } \\
\text { d } 1\end{array}$ & $\begin{array}{c}\text { Plasma } \\
\text { NEFA } \\
\text { d } 0\end{array}$ & $\begin{array}{c}\text { Plasma } \\
\text { NEFA } \\
\mathrm{d}-1 \\
\end{array}$ & $\begin{array}{c}\text { Plasma } \\
\text { NEFA } \\
\mathrm{d}-2\end{array}$ & $\begin{array}{c}\text { Plasma } \\
\text { BHBA } \\
\text { d } 1\end{array}$ & $\begin{array}{c}\text { Plasma } \\
\text { glucose } \\
\text { d } 1\end{array}$ & $\begin{array}{c}\text { Plasma } \\
\text { insulin } \\
\text { d } 1\end{array}$ \\
\hline \multirow[t]{2}{*}{ ASP } & 0.294 & -0.170 & 0.563 & -0.460 & -0.389 & 0.009 & -0.247 & -0.151 & -0.027 & -0.012 & -0.195 & -0.035 & 0.112 \\
\hline & 0.030 & 0.21 & $<0.001$ & $<0.001$ & 0.004 & 0.95 & 0.068 & 0.27 & 0.84 & 0.93 & 0.15 & 0.80 & 0.41 \\
\hline \multirow{2}{*}{$\mathrm{CO}_{2}$} & & -0.160 & 0.238 & -0.383 & -0.326 & -0.072 & 0.012 & -0.256 & -0.100 & -0.122 & -0.010 & 0.109 & 0.203 \\
\hline & & 0.24 & 0.080 & 0.004 & 0.016 & 0.61 & 0.93 & 0.059 & 0.468 & 0.37 & 0.94 & 0.43 & 0.137 \\
\hline \multirow[t]{2}{*}{$\mathrm{EP}$} & & & 0.646 & 0.554 & 0.492 & -0.402 & 0.613 & 0.262 & 0.239 & 0.220 & 0.197 & -0.211 & -0.097 \\
\hline & & & $<0.001$ & $<0.001$ & $<0.001$ & 0.002 & $<0.001$ & 0.053 & 0.079 & 0.11 & 0.15 & 0.12 & 0.480 \\
\hline \multirow{2}{*}{ Total metabolism } & & & & 0.120 & 0.122 & -0.309 & 0.339 & 0.090 & 0.216 & 0.143 & 0.060 & -0.197 & -0.010 \\
\hline & & & & 0.39 & 0.38 & 0.022 & 0.011 & 0.51 & 0.11 & 0.30 & 0.66 & 0.15 & 0.94 \\
\hline \multirow{2}{*}{ Liver total lipid } & & & & & 0.852 & -0.368 & 0.564 & 0.396 & 0.264 & 0.103 & 0.261 & -0.003 & -0.252 \\
\hline & & & & & $<0.001$ & 0.004 & $<0.001$ & 0.002 & 0.045 & 0.44 & 0.048 & 0.98 & 0.056 \\
\hline \multirow[t]{2}{*}{ Liver TAG } & & & & & & -0.458 & 0.527 & 0.430 & 0.183 & 0.173 & 0.292 & -0.063 & -0.254 \\
\hline & & & & & & $<0.001$ & $<0.001$ & 0.001 & 0.169 & 0.193 & 0.26 & 0.64 & 0.055 \\
\hline \multirow{2}{*}{ Liver glycogen } & & & & & & & -0.469 & -0.184 & -0.073 & -0.066 & -0.081 & 0.183 & 0.270 \\
\hline & & & & & & & $<0.001$ & 0.17 & 0.59 & 0.62 & 0.55 & 0.17 & 0.040 \\
\hline \multirow{2}{*}{ Plasma NEFA d 1} & & & & & & & & 0.522 & 0.462 & 0.395 & 0.374 & -0.072 & -0.337 \\
\hline & & & & & & & & $<0.001$ & $<0.001$ & 0.002 & 0.004 & 0.59 & 0.009 \\
\hline \multirow[t]{2}{*}{ Plasma NEFA d 0} & & & & & & & & & 0.734 & 0.700 & 0.653 & -0.227 & -0.385 \\
\hline & & & & & & & & & $<0.001$ & $<0.001$ & $<0.001$ & 0.083 & 0.003 \\
\hline \multirow[t]{2}{*}{ Plasma NEFA d -1} & & & & & & & & & & 0.804 & 0.584 & -0.286 & -0.367 \\
\hline & & & & & & & & & & $<0.001$ & $<0.001$ & 0.028 & 0.004 \\
\hline \multirow{2}{*}{ Plasma NEFA d -2} & & & & & & & & & & & 0.514 & -0.354 & -0.324 \\
\hline & & & & & & & & & & & $<0.001$ & 0.006 & 0.012 \\
\hline \multirow{2}{*}{ Plasma BHBA d 1} & & & & & & & & & & & & -0.276 & -0.316 \\
\hline & & & & & & & & & & & & 0.035 & 0.015 \\
\hline \multirow{2}{*}{ Plasma glucose d 1} & & & & & & & & & & & & & 0.206 \\
\hline & & & & & & & & & & & & & 0.12 \\
\hline
\end{tabular}

${ }^{1}$ Correlation coefficient $(\mathrm{r})$ is top number, with corresponding $P$-value beneath.
${ }^{2} \mathrm{ASP}=$ acid-soluble products; $\mathrm{EP}=$ esterified products; TAG $=$ triacylglycerol. 
cows fed ad libitum during the dry period than for cows fed in restricted amounts during the dry period, but sensitivity of CPT-1 to malonyl-CoA inhibition was not different between dietary groups (Dann and Drackley, 2005). Although malonyl-CoA was not measured in our study, we would expect cows that over-consumed the higher energy diet prepartum in our study to have greater hepatic concentrations of malonyl-CoA due to the chronically elevated insulin concentrations (Dann et al., 2006), which in turn would suppress fatty acid oxidation pathways in mitochondria (Jesse et al., 1986a).

Drackley (1999) and Drackley and Andersen (2006) suggested that insulin may be a major mediator of hepatic lipid accumulation in cows overfed during the dry period. However, in the current study in vitro metabolism of palmitate was not correlated with insulin concentrations in plasma. Our results contrast with earlier data from dairy cows. For example, in vitro administration of insulin inhibited palmitate oxidation to $\mathrm{CO}_{2}$ and ASP by bovine liver slices, but the effects of insulin on esterification were not measured (Jesse et al., 1986b). Fatty acid oxidation in liver slices was decreased when slices were obtained during a hyperinsulinemic, euglycemic clamp in dairy cows (Andersen et al., 2002), likely via the inhibitory effects of insulin on CPT-1 and the decrease in NEFA mobilization. Incubating hepatocytes from preruminant calves with insulin in the medium increased the proportion of oleate converted to cellular TAG (Cadórniga-Valiño et al., 1997), consistent with the effect of insulin to upregulate enzymes of TAG formation in rodent liver (Zammit, 1996).

We suggest, on the basis of data from this study, that the liver from cows overfed nutrients during the dry period is prone to lower rates of NEFA oxidation and a greater relative capacity for esterification of NEFA, thus making it more likely to accumulate TAG after parturition. The rate of synthesis of EP in liver slices from cows in this study peaked on $\mathrm{d} 1$ postpartum as observed previously (Grum et al., 1996), although actual TAG accumulation as a percentage of wet tissue weight (data not shown) peaked later on d 14 postpartum, similar to data from the entire set of cows in this experiment (Dann et al., 2006). Gene expression profiles of a subset of cows used in this study (Loor et al., 2006) help to explain the differences in rates of liver palmitate metabolism that we observed. Liver from cows fed 80NRC in both far-off and closeup periods had more pronounced upregulation of genes involved in hepatic NEFA oxidation such as CPT1A and adiponectin receptor 2 (ADIPOR2; Loor et al., 2006). In contrast to restricted energy feeding, NRC150 resulted in upregulation of genes associated with liver TAG synthesis such as diacylglycerol O-acyltransferase 1 (DGAT1; Loor et al., 2006). In contrast to the current and previous (Grum et al., 1996) studies, Van den Top et al. (1996) found no evidence for increased activities of enzymes involved with TAG synthesis in liver of cows that were overfed during the dry period compared with control cows. The reason for this apparent difference among experiments is not clear, although differences in experimental measurements (in vitro tissue flux in the current study and in Grum et al., 1996; mRNA in Loor et al., 2006; enzyme activities in Van den Top et al., 1996) must be acknowledged.

Rukkwamsuk et al. (1998) and Drackley (1999) suggested that prepartal strategies to adapt the liver to oxidize NEFA around parturition might benefit transition success. Although rates of total oxidation $\left(\mathrm{CO}_{2}\right.$ plus ASP) by liver homogenates did not differ significantly among periparturient dairy cows fed control, high fat, or high grain diets during the dry period, the high fat diet resulted in greater peroxisomal $\beta$-oxidation and lower esterification capacity in liver (Grum et al., 1996). Subsequent research demonstrated that the decreased liver TAG after calving in the study by Grum et al. (1996) were most likely caused by decreased DMI in the fat-supplemented group during the dry period (Douglas et al., 2006). Compared with limit-feeding to requirements, overfeeding during the dry period substantially decreased the basal lipolytic rate in adipose tissue prepartum, but resulted in a weakened antilipolytic response of adipose tissue to BHBA and glucose postpartum; as a consequence, more NEFA were released from adipose tissue (Rukkwamsuk et al., 1998). Because overfed cows had lower basal lipolytic rates prepartum, their livers may have been less adapted to oxidize NEFA around parturition (Grum et al., 1996; Rukkwamsuk et al., 1998). Thus, controlling energy intake during the dry period to meet but not greatly exceed requirements might result in adaptations in both adipose tissue and liver that favor lower postpartal TAG concentrations in liver.

The concentration of NEFA in plasma around parturition is strongly related to accumulation of TAG in liver (Vazquez-Añon et al., 1994). The relationships of daily plasma NEFA concentrations with hepatic lipid metabolism and TAG accumulation in our study provide useful insights. Late prepartal NEFA concentrations (d -1 and -2 ) were not strongly related to liver TAG or total lipid concentrations on d 1, nor were they correlated with palmitate metabolic activities in liver slices. In contrast, the NEFA concentration on the day of parturition (d 0) was positively correlated with hepatic concentrations of both total lipid and TAG, but was not related to in vitro rates of palmitate metabolism on d 1. However, the d 1 NEFA concentration was highly correlated with conversion of palmitate to EP as well as hepatic concentrations of total lipid and TAG. These 
associations support a role for increased NEFA concentration in blood at calving as a major factor leading to increased hepatic TAG after parturition. Vazquez-Añon et al. (1994) found that elevated NEFA on d 1 postpartum was strongly related to hepatic TAG accumulation. Our results provide no evidence that prepartum NEFA concentration was related to development of fatty liver postcalving, similar to previous results (Vazquez-Añon et al., 1994). Nor do our findings offer support for the idea that elevated NEFA prepartum leads to hepatic adaptations such as increased oxidative capacity that would help minimize lipid accumulation (Rukkwamsuk et al., 1998; Drackley, 1999).

In contrast, our data highlight the strong relationship between NEFA concentrations on the day of parturition and $\mathrm{d} 1$ postpartum with the degree of hepatic lipid accumulation. Moreover, our data indicate that one of the mechanisms for this effect of elevated NEFA, in addition to providing substrate for hepatic TAG formation, may be stimulation of the enzymatic activities for TAG synthesis in liver. This possibility should be investigated further.

The concentration of BHBA in plasma on d 1 postpartum was not correlated with hepatic palmitate metabolism in vitro (Table 6). In contrast to effects on hepatic TAG, however, d 1 BHBA in plasma was strongly correlated with NEFA concentrations in plasma on $d$ $-2, \mathrm{~d}-1$, and the day of calving. Plasma BHBA also was correlated with NEFA on d 1 postpartum but not as strongly as the prepartal values. Therefore, it seems that elevated NEFA concentrations prepartum may be more of a risk factor for increased ketogenesis after calving than for TAG accumulation. These effects appear to be driven more by substrate supply (i.e., NEFA concentration) than by alterations in hepatic tissue oxidative capacity. This finding is supported by the apparent lack of involvement of activity and malonyl-CoA sensitivity of CPT-1 in development of early postpartal ketosis (Dann and Drackley, 2005).

\section{CONCLUSIONS}

The capacity of bovine liver tissue to convert palmitate to EP is strongly increased during the early postpartal period, whereas total palmitate oxidation is increased only slightly. Therefore, palmitate (and likely other NEFA) from mobilization of adipose tissue TAG would be more likely to be converted to TAG in the liver. Although day relative to parturition had large effects on in vitro palmitate metabolism in liver, prepartum diets resulted in modifications of the overall time-related changes. The close-up period has been the subject of intense research on management strategies to optimize transition success, but, in this study, mark- edly different dietary intakes during the close-up period affected hepatic palmitate metabolism only minimally. In contrast, dietary treatment during the far-off period had a greater effect on postpartal palmitate metabolism in the liver than did intake of the close-up diet. Data from this study indicate that ad libitum feeding of moderate energy diets during the dry period (e.g., 150NRC) can decrease capacity for palmitate oxidation at $1 \mathrm{~d}$ postpartum and increase its hepatic partitioning toward esterification, which would favor deposition of TAG in liver. Controlled energy intake during the dry period seems to direct palmitate toward oxidation and away from esterification. Our data also highlight the importance of increased NEFA concentrations on the day of parturition and $1 \mathrm{~d}$ postpartum in leading to increased hepatic lipid accumulation; in contrast, NEFA concentrations on d 1 or d 2 before parturition were not correlated with postpartal lipid concentration in liver but were strongly correlated with d 1 BHBA concentrations. Increased plasma NEFA on d 1 postcalving may increase activity of the esterification pathway in liver tissue.

\section{ACKNOWLEDGMENTS}

The authors express appreciation to A. S. Hansen and D. Rincker (both of the Department of Animal Sciences, University of Illinois, Urbana) for assistance with laboratory assays.

\section{REFERENCES}

Andersen, J. B., D. G. Mashek, T. Larsen, M. O. Nielsen, and K. L. Ingvartsen. 2002. Effects of hyperinsulinaemia under euglycemic conditions on liver fat metabolism in dairy cows in early and midlactation. J. Vet. Med. A 49:65-71.

Bobe, G., J. W. Young, and D. C. Beitz. 2004. Pathology, etiology, prevention, and treatment of fatty liver in dairy cows. J. Dairy Sci. 87:3105-3124.

Brindle, N. P. J., V. A. Zammit, and C. I. Pogson. 1985. Regulation of carnitine palmitoyltransferase activity by malonyl-CoA in mitochondria from sheep liver, a tissue with low capacity for fatty acid synthesis. Biochem. J. 232:177-182.

Cadórniga-Valiño, C., R. R. Grummer, L. E. Armentano, S. S. Donkin, and S. J. Bertics. 1997. Effects of fatty acids and hormones on fatty acid metabolism and gluconeogenesis in bovine hepatocytes. J. Dairy Sci. 80:646-656.

Cremin, J. D. Jr., J. K. Drackley, D. E. Grum, L. R. Hansen, and G. C. Fahey Jr. 1994. Effects of reduced phenolic acids on metabolism of propionate and palmitate in bovine liver tissue in vitro. J. Dairy Sci. 77:3608-3617.

Dann, H. M., and J. K. Drackley. 2005. Carnitine palmitoytransferase-1 in liver of periparturient dairy cows: Effects of prepartum intake, postpartum induction of ketosis, and periparturient disorders. J. Dairy Sci. 88:3851-3859.

Dann, H. M., N. B. Litherland, J. P. Underwood, M. Bionaz, A. D'Angelo, J. W. McFadden, and J. K. Drackley. 2006. Diets during far-off and close-up periods affect periparturient metabolism and lactation in multiparous cows. J. Dairy Sci. 89:3563-3577.

Dann, H. M., D. E. Morin, M. R. Murphy, G. A. Bollero, and J. K. Drackley. 2005. Prepartum intake, postpartum induction of ke- 
tosis, and periparturient disorders affect the metabolic status of dairy cows. J. Dairy Sci. 88:3249-3264.

Douglas, G. N., T. R. Overton, H. G. Bateman II, H. M. Dann, and J. K. Drackley. 2006. Prepartal plane of nutrition, regardless of dietary energy source, affects periparturient metabolism and dry matter intake. J. Dairy Sci. 89:2141-2157.

Drackley, J. K. 1999. Biology of dairy cows during the transition period: The final frontier? J. Dairy Sci. 82:2259-2273.

Drackley, J. K., and J. B. Andersen. 2006. Splanchnic metabolism of long-chain fatty acids in ruminants. Pages 199-224 in Ruminant Physiology: Digestion, Metabolism and Impact of Nutrition on Gene Expression, Immunology and Stress. K. Sejrsen, T. Hvelplund, and M. O. Nielsen, ed. Wageningen Academic Publishers, Wageningen, the Netherlands.

Drackley, J. K., D. C. Beitz, and J. W. Young. 1991a. Regulation of in vitro metabolism of palmitate by carnitine and propionate in liver from dairy cows. J. Dairy Sci. 74:3014-3024.

Drackley, J. K., D. C. Beitz, and J. W. Young. 1991b. Regulation of in vitro palmitate oxidation in liver from dairy cows during early lactation. J. Dairy Sci. 74:1884-1892.

Grum, D. E., J. K. Drackley, and J. H. Clark. 2002. Fatty acid metabolism in liver of dairy cows fed supplemental fat and nicotinic acid during an entire lactation. J. Dairy Sci. 85:3026-3034.

Grum, D. E., J. K. Drackley, R. S. Younker, D. W. LaCount, and J. J. Veenhuizen. 1996. Nutrition during the dry period and hepatic lipid metabolism of periparturient dairy cows. J. Dairy Sci. 79:1850-1864.

Hughes, J. P. 1962. A simplified instrument for obtaining liver biopsies in cattle. Am. J. Vet. Res. 23:1111-1113.

Jesse, B. W., R. S. Emery, and J. W. Thomas. 1986a. Control of bovine fatty acid oxidation. J. Dairy Sci. 69:2290-2297.

Jesse, B. W., R. S. Emery, and J. W. Thomas. 1986b. Aspects of the regulation of long-chain fatty acid oxidation in bovine liver. J. Dairy Sci. 69:2298-2303.

Littell, R. C., G. A. Milliken, W. W. Stroup, and R. D. Wolfinger. 1996. SAS System of Mixed Models. SAS Institute, Cary, NC.

Loor, J. J., H. M. Dann, N. A. Janovick Guretzky, R. E. Everts, R. Oliveira, C. A. Green, N. B. Litherland, S. L. Rodriguez-Zas, H.
A. Lewin, and J. K. Drackley. 2006. Plane of nutrition prepartum alters hepatic gene expression and function in dairy cows as assessed by longitudinal transcript and metabolic profiling. Physiol. Genomics 27:29-41.

Loor, J. J., R. E. Everts, M. Bionaz, H. M. Dann, D. E. Morin, R. Oliveira, S. L. Rodriguez-Zas, J. K. Drackley, and H. A. Lewin. 2007. Nutrition-induced ketosis alters metabolic and signaling gene networks in liver of periparturient dairy cows. Physiol. Genomics $32: 105-116$

Murondoti, A., R. Jorritsma, A. C. Beynen, T. Wensing, and M. J. H. Geelen. 2004. Unrestricted feed intake during the dry period impairs the postpartum oxidation and synthesis of fatty acids in the liver of dairy cows. J. Dairy Sci. 87:672-679.

NRC. 2001. Nutrient Requirements of Dairy Cattle. 7th rev. ed. Natl. Acad. Sci., Washington, DC.

Rukkwamsuk, T., T. Wensing, and M. J. H. Geelen. 1998. Effect of overfeeding during the dry period on regulation of adipose tissue metabolism in dairy cows during the periparturient period. J. Dairy Sci. 81:2904-2911.

Van den Top, A. M., M. J. H. Geelen, T. Wensing, G. H. Wentink, A. T. Van't Klooster, and A. C. Benyen. 1996. Higher postpartum hepatic triacylglycerol concentrations in dairy cows with free rather than restricted access to feed during the dry period are associated with lower activities of hepatic glycerolphosphate acyltransferase. J. Nutr. 126:76-85.

Vazquez-Añon, M., S. Bertics, M. Luck, R. R. Grummer, and J. Pinheiro. 1994. Peripartum liver triglyceride and plasma metabolites in dairy cows. J. Dairy Sci. 77:1521-1528.

Veenhuizen, J. J., J. K. Drackley, M. J. Richards, T. P. Sanderson, L. D. Miller, and J. W. Young. 1991. Metabolic changes in blood and liver during development and early treatment of experimental fatty liver and ketosis in cows. J. Dairy Sci. 74:4238-4253.

Zammit, V. A. 1996. Role of insulin in hepatic fatty acid partitioning: Emerging concepts. Biochem. J. 314:1-14.

Zammit, V. A. 1999. The malonyl-CoA-long-chain acyl-CoA axis in the maintenance of mammalian cell function. Biochem. J. 343:505-515. 